Original Research

\title{
Analysis of Toxic Chemical Substance Present in Wastewater Samples Around the Urban Area of Tirupati, Andhra Pradesh
}

\author{
Raju Katepogu ${ }^{1 *}$, Maheswaramma Goda ${ }^{2}$, Chandraiah Tanguturu ${ }^{3}$ \\ ${ }^{1}$ Sri Venkateswara College of Engineering Near Karakambadi Road, Opp Lic Training Center, \\ Tirupati-517507, Andhra Pradesh, India \\ ${ }^{2}$ Key Laboratory of Environmental Science, Dept. of Science and Humanities, Sri Venkateswara College of Engineering, \\ Tiruapti-517507, Andhra Pradesh, India \\ ${ }^{3}$ Dept. of Science and Humanities, Sri Venkateswara College of Engineering, Tiruapti-517507, Andhra Pradesh, India
}

Received: 8 July 2019

Accepted: 15 October 2019

\begin{abstract}
The world is facing problems with a wide variety of pollutants and contaminants from various developmental activities. The population explosion is one reason for an increase in polluted wastewater from various sources like industrialization and urbanized societies. Essentially, all human beings, plants and animals need water to be sustained, and abnormal environmental changes are occurring through toxic substances such as nitrate, nitrite, sulfide, sulphate, sodium, potassium, cadmium, lead, chromium, iron, and mercury that enter land and water bodies. Those are the drastic influences on terrestrial ecosystem, besides environmental decline disturbing daily human life. The present study focused on the physicochemical analysis of wastewater around the industrial urban area of Tirupati. The analytical standard methods were followed. The results represent that the colour of the collected samples were brown and unpleasant. The conductivity values ranged from 120-180 $\mu \mathrm{S} / \mathrm{cm}\left(\mathrm{S}_{1}-\mathrm{S}_{4}\right)$ results of high salts. The turbidity range was about 32-28 NTU( $\left.\mathrm{S}_{1}-\mathrm{S}_{4}\right)$. The hardness of wastewater was noted at $420-520 \mathrm{mg} / \mathrm{l}$. The total solids were found to be $600-1300 \mathrm{mg} / \mathrm{l}$ and the salinity values varied from 220-290 mg/l. The Alkalinity of water values ranged from 220-290 mg/l, which were further confirmed by $\mathrm{pH}$ measurements obtained as $10.5,8.8,7.99$, and $7.82\left(\mathrm{~S}_{1}, \mathrm{~S}_{2}, \mathrm{~S}_{3}\right.$ and $\left.\mathrm{S}_{4}\right)$ respectively. Currently, the results were remarkably highly polluted and may cause harmful skin diseases and eye maladies, and even damage to kidney functions. The presence of ionic chloride values shows $300-530 \mathrm{mg} / 1$ and total suspended solids (TSS) values were $300-550 \mathrm{mg} / 1$. The maximum total dissolved solids (TDS) are in the range of 300-800 ppm. Furthermore, the dissolved oxygen (DO) was determined at about 5.5-7.66 mg/1 and biological oxygen demand (BOD) values of 102-92.4 ppm were noticed, whereas volatile organic compounds (VOC) values ranged 1.2-2.8 $\left(\mathrm{S}_{1}-\mathrm{S}_{4}\right)$. The high volatile organic substances produce a pungent smell. Analysis methodology results were compared with the Bureau of Indian Standards (BIS) along with environmental protection rules from 1986 and ISO 10500-2012 standards.
\end{abstract}

*e-mail: envirosvu@gmail.com 
The studies significantly represent the possiblility of contamination of surrounding living systems being drastically disturbed regarding growth and development. The conclusion is that water bodies around urban areas of Tirupati were highly polluted due to the discharge of waste materials either directly or indirectly dumped into the water bodies, and pollution control boards and municipalities are not taking serious actions, which may continuously increase the anaerobic and hygine problems that could spread viruses and insect populations and that may affect all living organisms.

Keywords: total dissolved solids, dissolved oxygen, biological oxygen demand and volatile organic compounds

\section{Introduction}

Water is one of the most valuable abundant natural resources for all living creatures on the earth and is essential for sustaining life as exemplified by its diversified uses such as drinking, cooking, washing, irrigating, farming, and industrial activities [1]. Water scarcity is a major problem for sustaining life in the very near future. There is an estimated requirement for water of 85 liters per capita per day (lpcd) at present, to 125 and 170 lpcd by 2025 and 2050 , due to rapid economic growth and increased population [2]. The urban population is growing exponentially every year, water is a basic requirement for humans to utilize not only for direct consumption, but also for a production of various needs such as food services, animal feed and much more [3]. Worldwide, $52 \%$ of the people are living in urban cities, and today the running of the urban water cycle (both freshwater and wastewater) in cities becomes of utmost importance [4]. The proper implementation of urban water recycling will increase to meet sanitary requirements for a growing population to ensure good water quality in urban areas [5]. The term "wastewater" properly means any water that is no longer used directly, as no further benefits can be derived out of it. The content of wastewater $\sim 95 \%$ of its water, and only $\sim 1-5 \%$ is solid substances [6]. Pollutants from wastewater are a potential health risk and are toxic to aquatic organisms [7]. Wastewater treatment helps to remove contaminants from water, leading to a decreased pollutant load. Water pollution occurs through natural processes in some cases, with most of the pollution caused by human activities [8]. The used water of a community is called wastewater or sewage. Sewage water is the cause of serious pollution in a particular environment [9]. The overuse and logging of water has an index of shortage. The industrial waste deposited into water bodies makes it unfit for consumption [10], and pollutants from wastewater are harmful to communal health and the surroundings, and are also toxic to aquatic organisms. Wastewater treatment needs to remove contaminants from water to become less pollutant then load [11]. This may cause diseases to more living organisms in and around the areas, and ultimately impacts the socio-economic environmental disorder. The present work focuses on identifying harmful substances both ionic as well as organic substances like Benzene, Aniline, Phenol, Acrylate monomers and inorganics. It may impact the reduction of biological waterborne diseases around the studied areas. The used water assessment of receiving water quality relied heavily on measurement of organic loading (BOD, COD) and bacteriological quality [12].

\section{Sample Collection and Preparation}

The samples were collected in the morning at Renigunta and Karakambadi village areas of latitude $36.6288^{\circ} \mathrm{N}-79.4192^{\circ} \mathrm{E}$, Tirupati urban, Chittoor District, Andhra Pradesh, India. The industrial Wastewater samples were randomly collected from selected areas in the morning from January to March 2019. Before collection, the sample bottles were rinsed three times with the sample before being filled. The areas of the samples were to receive through different areas of pollution loaded wastewater. The samples were collected in $250 \mathrm{ml}$ brown glass bottles that had been washed with ultrapure water and rinsed with acetone and dried in an oven [13]. Then, the water samples were brought back to the laboratory and stored at $4^{\circ} \mathrm{C}$ prior to analysis. The actual sampling was done by dipping the sampling bottles at approximately $20-30 \mathrm{~cm}$ inside the surrounding area. The samples were then transported in cooler boxes immediately to the laboratory for further analysis. The samples were used to further advance characterization for physiochemical parameters, additionally being precleaned by washing with nonionic detergents and rinsed with distilled water several times. The dissolved oxygen was fixed with Winkler solution A and Winkler solution B and cooled until being brought to the laboratory for analysis.

\section{Materials and Methods}

Water quality was analyzed using Standard Methods APHA-AWWA-WEF (1998). All the equipment was checked and calibrated according to the manufacture specification, all four samples were characterized based on color. The $\mathrm{pH}$ meter was calibrated using $\mathrm{HACH}$ (1997) buffers of $\mathrm{pH} 4.0,7.0$ and 10.0. The $\mathrm{pH}$ values recorded for all the sampling points were above the WHO pH acceptance limit in the span of 6.00-9.00 for 
Table 1. Physio chemical analysis at Renigunta Industrial Site-I.

\begin{tabular}{|c|c|c|c|}
\hline S.NO. & Name of the Parameter & *Sample-I mg/l & *Sample-II mg/l \\
\hline 1 & Colour & Brown & $8.8 \pm 0.2$ \\
\hline 2 & $\mathrm{pH}$ & $10.15 \pm 0.2$ & $150 \pm 0.2$ \\
\hline 3 & $\mathrm{EC}$ & $120 \pm 0.2$ & $30 \pm 0.3$ \\
\hline 4 & Turbidity & $32 \pm 0.2$ & $460 \pm 0.8$ \\
\hline 5 & Hardness & $420 \pm 0.9$ & $1200 \pm 0.2$ \\
\hline 6 & Total Solids & $600 \pm 0.22$ & $280 \pm 0.1$ \\
\hline 7 & Salinity & $200 \pm 0.12$ & $270 \pm 0.3$ \\
\hline 8 & Alkanity & $220 \pm 0.3$ & $32 \pm 0.8$ \\
\hline 9 & Acidity & $26 \pm 0.5$ & $520 \pm 0.1$ \\
\hline 10 & Chlorides & $300 \pm 0.6$ & $540 \pm 0.9$ \\
\hline 11 & TSS & $300 \pm 0.5$ & $420 \pm 0.6$ \\
\hline 12 & TDS & $300 \pm 0.2$ & $6.4 \pm 0.25$ \\
\hline 13 & DO & $5.5 \pm 0.20$ & $95 \pm 0.8$ \\
\hline 14 & BOD & $102 \pm 0.5$ & $1.9 \pm 0.29$ \\
\hline 15 & VOC & $1.2 \pm 0.24$ & \\
\hline All & & & \\
\hline
\end{tabular}

All the samples are analysis in mean \pm S.E

All the samples are in mean \pm S.E D.O $=$ Dissolved oxygen, $\mathrm{BOD}=$ Biological Oxygen Demand. TDS $=$ Total dissolved solids.

wastewater to be discharged into the channel. Turbidity levels and total suspended solids of the wastewater samples were determined using standard procedures. The conductivity measurements were done by adjusting the temperature and the instrument was calibrated with $0.001 \mathrm{M} \mathrm{KCl}$ to the value of $14.7 \mu \mathrm{S} / \mathrm{m}$ at $25^{\circ} \mathrm{C}$. The probe was dipped below the surface of the wastewater. Time was allowed to stabilize and be recorded. Hardness, total solids (TS), salinity, alkalinity, acidity, ionic chlorides, total suspended solids (TSS), total dissolved solids (TDS), and dissolved oxygen (DO) were determined. The instruments were calibrated prior to sampling. The dissolved oxygen was done using solution $(5 \% \mathrm{HCl})$ in accordance with the manufacturer's

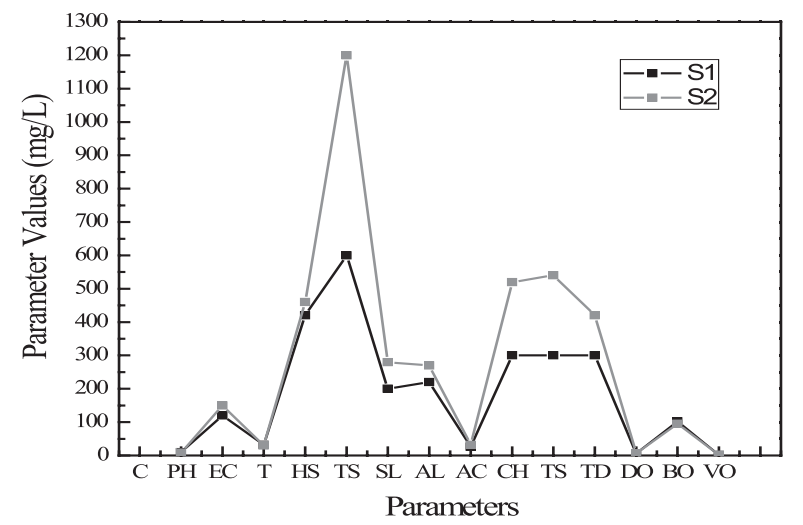

Fig. 1. Corresponding values were represented in graphical method. instructions. Biological oxygen demand (BOD) and volatile organic compounds of wastewater samples was determined in $\mathrm{mg} / \mathrm{l}$ carried out using standard methods described by Ademoroti (1996) and the American Public Health Association (APHA). The samples were analyzed according to the standard methods [14]. The other parameters of the wastewater samples were analyzed by triplicate by adapting standard procedures from the APHA manual. A UV-Visible (UV-VIS) spectrophotometer was used (Systronics PC based double beam spectrophotometer 2206 bandwidth $1 \mathrm{~nm}$ ). The analyzed samples were diluted 10 times with ultrapure water to further the sample adjusted to $\mathrm{pH} 7$. UV-VIS spectroscopy was performed with ultrapure

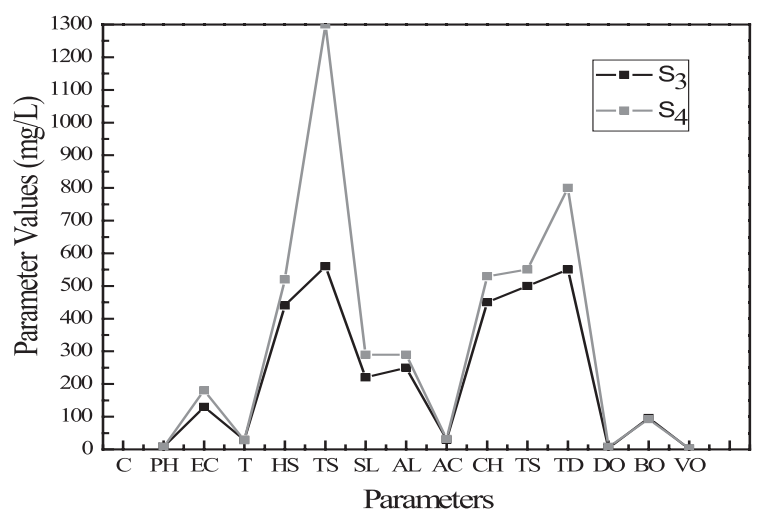

Fig. 2. Corresponding values were represented in graphical method. 
Table 2. Physiochemical analysis at Renigunta Industrial Site-II,

\begin{tabular}{|c|c|c|c|}
\hline S.NO. & Name of the Parameter & *Sample-III mg/l & *Sample-IV mg/l \\
\hline 1 & Colour & Light brown & $7.82 \pm 0.2$ \\
\hline 2 & PH & $7.79 \pm 0.2$ & $180 \pm 0.30$ \\
\hline 3 & EC & $130 \pm 0.15$ & $28 \pm 0.22$ \\
\hline 4 & Turbidity & $29 \pm 0.19$ & $520 \pm 0.26$ \\
\hline 5 & Hardness & $440 \pm 0.21$ & $1300 \pm 0.36$ \\
\hline 6 & Total Solids & $560 \pm 0.32$ & $290 \pm 0.29$ \\
\hline 7 & Salinity & $220 \pm 0.26$ & $290 \pm 0.30$ \\
\hline 8 & Alkanity & $250 \pm 0.32$ & $32 \pm 0.16$ \\
\hline 9 & Acidity & $30 \pm 0.12$ & $530 \pm 0.11$ \\
\hline 10 & Chlorides & $450 \pm 0.9$ & $550 \pm 0.37$ \\
\hline 11 & TSS & $500 \pm 0.32$ & $800 \pm 2.5$ \\
\hline 12 & TDS & $550 \pm 2.3$ & $7.66 \pm 0.28$ \\
\hline 13 & DO & $4.6 \pm 0.23$ & $92.4 \pm 0.22$ \\
\hline 14 & BOD & $96.5 \pm 0.21$ & $2.8 \pm 0.20$ \\
\hline 15 & VOC & $1.8 \pm 0.18$ & \\
\hline
\end{tabular}

All the samples are in mean \pm S.E D.O = Dissolved oxygen,

$\mathrm{BOD}=$ Biological Oxygen Demand TDS $=$ Total dissolved solids.

water as the control [29]. The scanning conditions were wavelength ranges of 200-600 $\mathrm{nm}$, data acquisition precision was $0.5 \mathrm{~nm}$, and a cuvette used a $1 \mathrm{ml}$ quartz cell (Q-104, 81.9). The values of $\mathrm{pH}$ were measured with an ESICO precision $\mathrm{pH}$ meter (Model alpha-01). Total suspended solid of the wastewater samples were determined using standard procedure [15].

\section{Results and Discussion}

Physical parameters such as $\mathrm{pH}$, alkalinity, dissolved oxygen, and transparency (turbidity) were important in determining the effects of wastewater dischar,ge and the effects of natural process experiments are represented in Tables 1 and 2. Initially, the samples were clearly brown or light brown colour. The $\mathrm{pH}$ of wastewater was 10.5-7.82 $\mathrm{S}_{1}$ to $\mathrm{S}_{4}$. There was no significant difference $(\mathrm{P}<0.02)$ indicated by the presented study areas [16]. Electrical conductivity of water, a useful and easy indicator of its salinity, was $120-180 \mu \mathrm{S} / \mathrm{cm}$, and the results of soluble salts can be responsible for $\mathrm{S}_{1}-\mathrm{S}_{4}$. The highest value was observed in $\mathrm{S}_{4}$ at $180 \mu \mathrm{S} / \mathrm{cm}$ and the lowest value was noted in $\mathrm{S}_{1}$ at $120 \mu \mathrm{S} / \mathrm{cm}$. There was a highly significant difference $(\mathrm{P}<0.01)$ in the mean values of conductivity among the study areas. Turbidity relates to the look or clearness of a water sample and is the result of suspended matter. The turbidity values ranged 32-28. The hardness values ranged from 420 to 520 in $\mathrm{S}_{1}-\mathrm{S}_{4}$ respectively [17]. The highest value was recorded in $\mathrm{S}_{4}(520)$ and the lowest value was recorded in $S_{1}$ (420). The mean total solid values ranged from $600 \mathrm{mg} / \mathrm{l}$ and $1300 \mathrm{mg} / \mathrm{l}$ in $\mathrm{S}_{1}$ and $\mathrm{S}_{4}$. The salinity range values for both samples were $200-290 \mathrm{mg} / \mathrm{l}$ respectively. The salinity values from the study areas of the samples, however, were not significantly different $(\mathrm{P}<0.05)$. The alkalinity was taken as $\mathrm{CaCO}_{3}$ with values ranging from $220-290 \mathrm{mg} / 1 \mathrm{~S}_{1}-\mathrm{S}_{4}$. The acidity values ranging from $26-32 \mathrm{mg} / \mathrm{l}$ were valued in $\mathrm{S}_{1}$ to $\mathrm{S}_{4}$. The chloride values ranged from $300-530 \mathrm{mg} / 1$ in $\mathrm{S}_{1}-\mathrm{S}_{4}$. The mean total suspended solid (TSS) range values for $\mathrm{S}_{1}-\mathrm{S}_{4}$ were recorded as $300-550 \mathrm{mg} / \mathrm{l}$. The TSS values obtained from the study areas had no significant difference $(\mathrm{P}<0.05)$. Total dissolved solids (TDS) for both samples were recorded as 300-800 mg/l. Dissolved oxygen (DO) fluctuated between $5.5-7.66 \mathrm{mg} / \mathrm{l}$. The highest value $7.66 \mathrm{mg} / 1$ recorded in $\mathrm{S}_{4}$ indicated a high percentage of pollution by organic matter [18]. The standard for sustaining aquatic life is stipulated as $5 \mathrm{mg} / \mathrm{l}$ below this value, which may lead to death for most fish. The DO values of $\mathrm{S}_{1}$ to $\mathrm{S}_{4}$ are above the recommended values. There was no significant difference $(\mathrm{P}<0.05)$ among study areas. Biological oxygen demand (BOD) values recorded were in the range of $102-92 \mathrm{mg} / \mathrm{l}$ for both $\mathrm{S}_{1}$ and $\mathrm{S}_{4}$ respectively. There was no significant difference $(\mathrm{P}<0.05)$ among the study areas. The volatile organic compound (VOC) values range from 1.2-2.8 $\mathrm{mg} / \mathrm{L} \mathrm{S}_{1}$ and $\mathrm{S}_{4}$ respectively [19]. The values significant difference $(\mathrm{P}<0.05)$ among study. The major problems connected with the spread of industrial and urban wastes are generated by human activities, which are the contamination of water and soil, the controlled and 


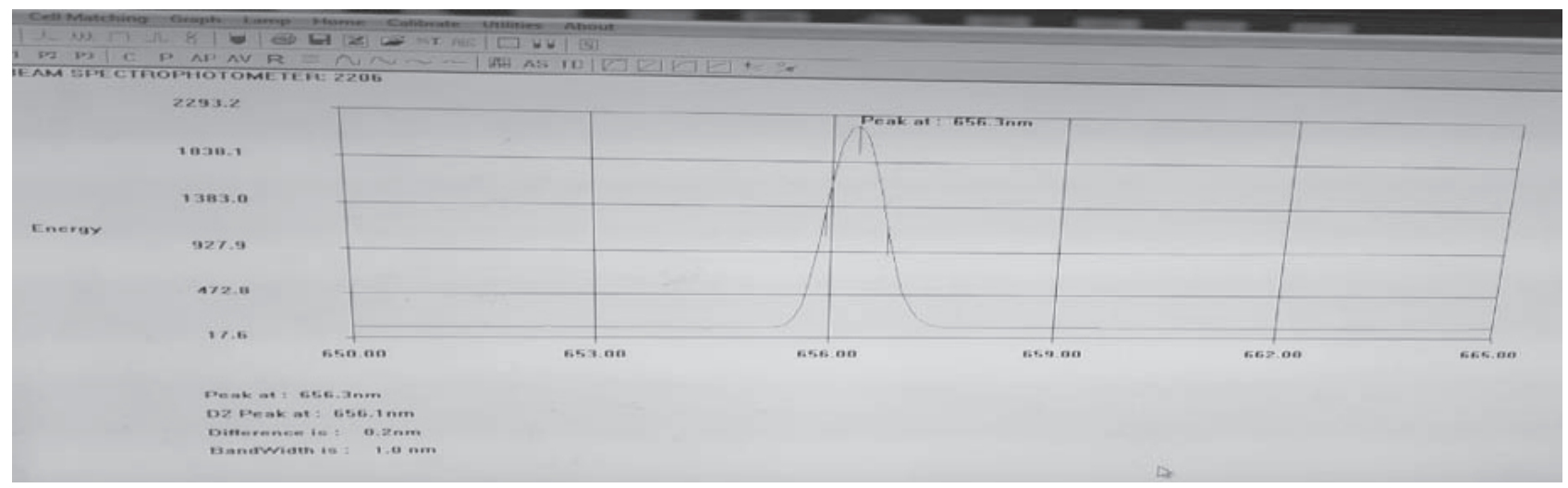

Fig. 3. UV-Visible peak of reference with distilled water.

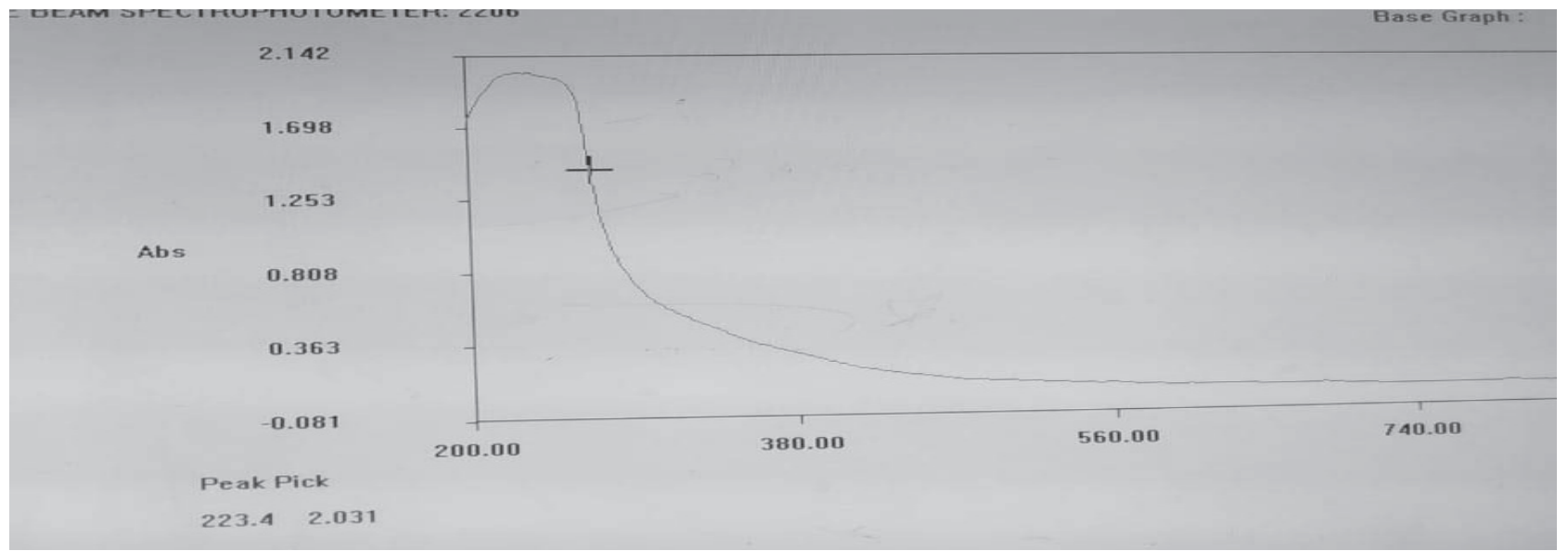

Fig. 4. UV-Visible absorption maxima ( $\lambda \max ) 223 \mathrm{~nm}$ for sample 1 collected at Renugunta industrial area Tirupati.

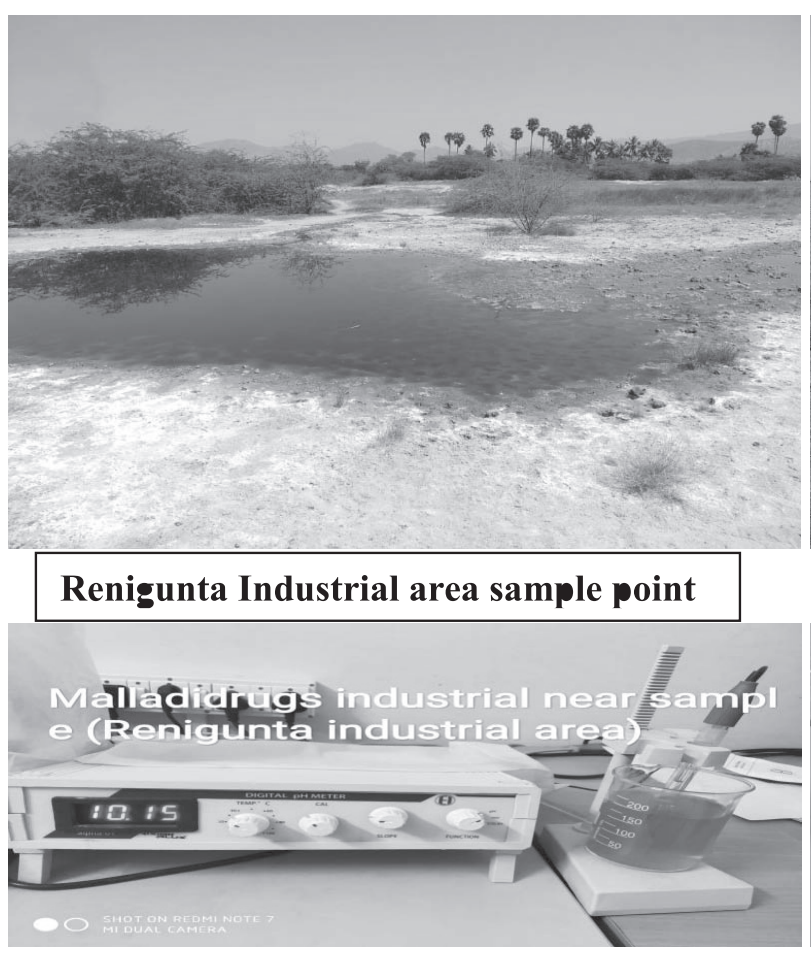

Fig. 5. pH meter.

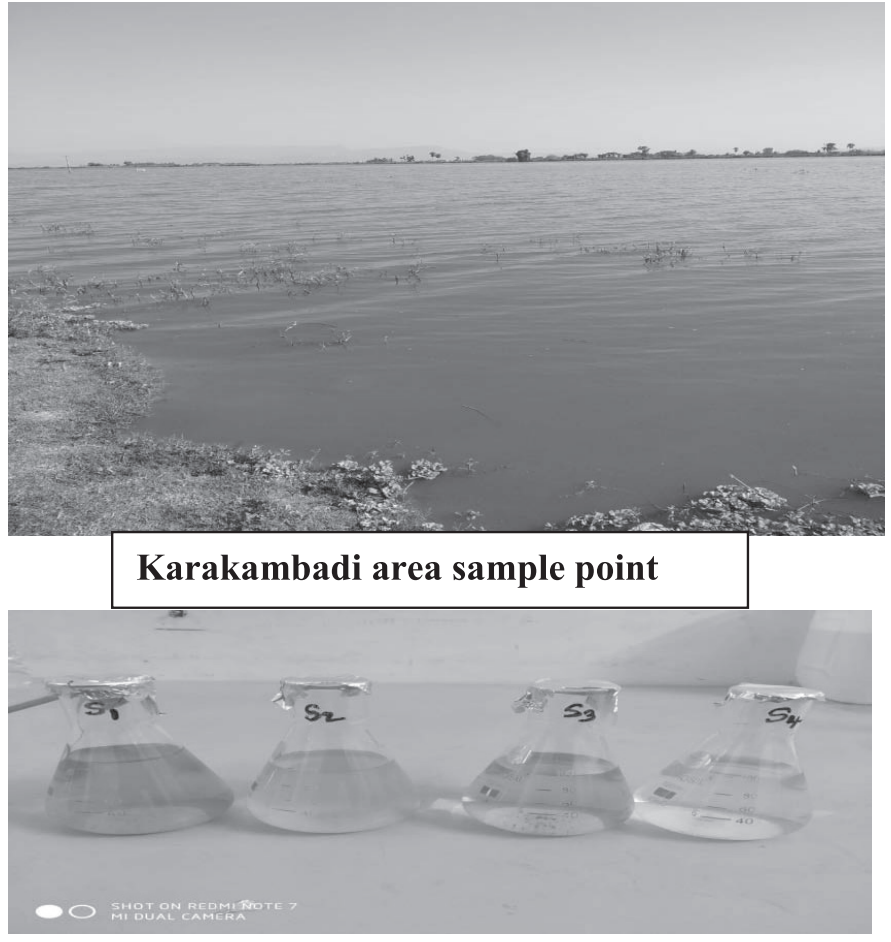

Fig. 6. Collected wastewater samples. 
Table 3. Classical methods of analysis.

\begin{tabular}{|c|c|c|}
\hline Constituent & Parameter & Method \\
\hline \multirow{2}{*}{ Solids } & Total solids & Gravimetric \\
& Volatile solids \\
& Total suspended solids \\
Volatile suspended solids & Bioassay \\
& Biochemical oxygen demand (BOD) & Digestion \\
Organics & Chemical oxygen demand (COD) & Titrimetric \\
& Volatile organic acids & Gravimetric \\
\hline & Oil and grease & Electrometric \\
& Titrimetric \\
Physical & Ph & Titrimetric \\
& Alkalinity & Nephelometric, \\
& Dissolved oxygen & visual comparison \\
\hline Metals & Turbidity & Spectrophometer \\
\hline
\end{tabular}

uncontrolled disposal of wastes, process spillage, and sewage sludge application to agricultural soils [20]. $\mathrm{pH}$ of 10.15-8.8 and 7.79-7.82 were recorded in samples like $\mathrm{S}_{1}-\mathrm{S}_{4}$ respectively. The low $\mathrm{pH}$ of 8.5 at the contact point which is the concentration of the wastewater coming out of the pond area were not free for polluting most of the surface water serious threat to groundwater also. The nature of wastewater is capable of stemming the $\mathrm{pH}$ of their respective receiving water, thereby destabilizing fundamental properties such as acidity, alkalinity, salinity and metal solubility and hardness of the water [21]. Total solids and total dissolved solids of $800 \mathrm{mg} / 1$ in wastewater analysis were observed in that most of the particles are in water that is either in suspended as well as dissolved salts, which make water unfit for drinking and domestic purposes. The water contaminated with more dissolved solids affected the microorganisms, and human kidney problems may also increase [22]. The presence of chemical substance increasing different levels was observed and the concentrations of sodium, magnesium iron and to some extent calcium ions might be enhanced. Total suspended solids (TSS) mean ranged from $300-550 \mathrm{mg} / 1$, clearly suggesting more degradable organic matter. If this wastewater is applied directly to agricultural fields or discharged into rivers and streams, this could make it unsuitable for aquatic life [23]. For total dissolved solids (TDS), values obtained for all samples assayed were within the permissible limit set by FEPA. Polluted wastewater contains low levels of dissolved oxygen (DO) as a result of heavy biological oxygen demand (BOD) and is placed by effluent discharged into surface water [24]. This makes wastewater unsuitable for drinking and irrigation or any other use. The biological oxygen demand (BOD) is a useful parameter for water quality analysis [25]. BOD is a function of DO. The decreases in DO will lead to an increase in BOD values (Tables 1-2). This will cause oxygen depletion and may cause suffocation to fish and other aquatic organisms. Organic compounds may enter a water environment through human waste disposal and industrial discharge [26]. Lead is an expected pollutant in a battery factory because it is one of the raw materials. The high salinity of water may also increase the salinity of water $\mathrm{NaCl}, \mathrm{K}_{2} \mathrm{SO}_{4}$, sulfur, and nitrites may adversely affect the aquatic biota. The advantage of BOD is a parameter to examine biological oxidized concentrations of organic matter [27]. The greater the decomposable matter content, the greater the oxygen demand and the greater the BOD value. Continuing to lower the BOD values affecting the quality of fresh water can cause harm to aquatic life - especially downsteam fish [28].

\section{UV Spectrophotometer Analysis}

The advantage of using a UV spectrophotometer is that it is a quite easy and simple method to study the qualitative analysis of industrial wastewater. UV spectra give inorganic content metal complexes as well as organic aromatic pollutants [29]. The absorbance at the wavelength of $223 \mathrm{~nm}$ is associated with organically degraded protein-like substances, surfactants, and anthropogenics, and the existence of nitrite/nitrate, sulfide, and organic matter. These results are corroborated with turbidity values [30].

\section{Conclusions}

The present data collected from this physicochemical analysis of wastewater were clearly observed, and the water become polluted for $\mathrm{S}_{1}, \mathrm{~S}_{2}, \mathrm{~S}_{3}$ and $\mathrm{S}_{4}$, showing high levels of all the parameters. This must be a result of water coming from industrial discharge through waterways near Tirupai urban area. The community, which uses this pond water for various purposes for their daily needs, has suffered from skin diseases, and internal organs also would be damaged by the pond water. Animals who use that water have suffered from various digestive problems and have even died. 
Agricultural crop plants resist sensitivity for this period and even at lower concentrations of chemical toxicity in their bodies they may be condensed to crop growth and yield capacity. The pond water is directly used for domestic purposes, irrigation, fishing and other needful things that must follow the treatment methods by the ' $3 \mathrm{R}$ ' concept. Results show that $\mathrm{pH}$ of wastewater since the major contaminated raw material is tetraoxosulphate (VI) $\mathrm{H}_{2} \mathrm{SO}_{4}$ acid. High $\mathrm{pH}$ also affects aquatic life toxicity to the water body. The high levels of conductivity as well as high amounts of dissolved salts are in addition to metals like $\mathrm{Pb}, \mathrm{Fe}, \mathrm{Zn}$ and $\mathrm{Cu}$. These adversely affect the $\mathrm{pH}$, which could increase the solubility of many other elements like $\mathrm{Al}, \mathrm{B}, \mathrm{Si}, \mathrm{Cd}, \mathrm{Hg}$, $\mathrm{Mn}, \mathrm{Pd}, \mathrm{Zn}, \mathrm{Fe}$ and $\mathrm{Cu}$ that are needed for metabolism of some extremely toxic metals like $\mathrm{Al}, \mathrm{Cd}$, and $\mathrm{Pd}$ at trace level concentrations (ppb). The present study exposes the possibility of industrial effluents posing an environmental risk if not properly treated before being discharged into the receiving stream. Although a very large extent by comparing the physicochemical quality of wastewater as a result of their processes, which may conclude that some analysis was more dangerously affected to the living organisms directly or indirectly, when it was not in a treated process. The wastewater must be treated in a scientific manner and recycled for further reuse around the studied areas. This could be better for the sustenance of humans as well as flora and fauna species.

\section{Acknowledgements}

Sincere and special thanks to DST-SERB under the scheme of EMEQ New Delhi, India (File No.EEQ/2017/000596) for the financial support to the completion of this research work.

\section{Conflict of Interest}

The authors declare no conflict of interest.

\section{References}

1. KUMAR M., PURI A. A review of permissible limits of drinking water. Indian. J. Occup. Environ. Med. 16, 40, 2012.

2. GLEICK PETER H. Basic water requirements for human activities: Meeting basic needs. Water Int. 21 (2), 83, 1996.

3. CLOSAS ALVAR., SCHURING M., RODRIGUEZ D. Integrated urban water management lessons and recommendations from regional experiences in Latin America, Central Asia, and Africa. No. 75043. The World Bank, 2012.

4. TESFALEM BELAY WOLDEAMANUALE. Study on Physico- Chemical Parameters of Waste Water Effluents from Kombolcha and Debreberhan Industrial Area,
Ethiopia. International journal of Rural Development Environment and Health Research. 1 (2), 2017.

5. ZHANG L Y., ZHANG L., LIU Y. D., SHEN Y. W., LIU H., XIONG Y. Effect of limited artificial aeration on constructed wetland treatment of domestic wastewater. Desalination. 250, 915, 2010.

6. CHAUHAN RAVISH KUMAR. Physico-Chemical Analysis of Untreated Sewage Water of Ladwa town of Kurukshetra District of Haryana and Need of Waste Water Treatment Plant. Int J. Curr Microbiol. Appl. Sci. 3 (3), 326, 2014.

7. RATHORE D.S., RAI N., ASHIYA P. Physico Chemical Analysis of Water of Ayad River at Udaipur, Rajasthan (India). International Journal of Innovative Research in Science Engineering and Technology. 3 (4), 11660, 2014.

8. WU SHUBIAO., AUSTIN DAVID., LIU LIN., DONG RENJIE. Performance of integrated household constructed wetland for domestic wastewater treatment in rural areas. Ecol. Eng. 37 (6), 948, 2011.

9. KAMAL P., HEMANGI D., HITESHD. Impact of industrialization and urbanization on water quality of river Tapi Surat, Gujarat, India. J. Environ. Res. Dev. 9 (2) , 306, 2014.

10. WANG Y., WANG P., BAI Y., TIAN Z., LI J., SHAO X., MUSTAVICH L. F., LI B.L. Assessment of surface water quality via multivariate statistical techniques: a case study of the Songhua River Harbin region, China. J. Hydro Environ. Res. 7, 30, 2013.

11. BHATNAGARA AMIT., SILLANPA MIKA. Utilization of agro-industrial and municipal waste materials as potential adsorbents for water treatment A review. Chem. Eng. J. 157, 277, 2010.

12. TRUONG HOANG DAN., LE NHAT QUANG., NGUYEN HUU CHIEM., BRIX HANS. Treatment of high-strength wastewater in tropical constructed wetlands planted with Sesbania sesban. Horizontal subsurface flow versus vertical downflow. Ecol. Eng. 37, 711, 2011.

13. APHA Standard Methods for the Examination of Water and Waste water, $20^{\text {th }}$ edition, Washington, D.C.1998.

14. APHA Standard Methods of Examination of Water and Waste water, $10^{\text {th }}$ edition, Washington, D.C. 1992.

15. YUQIONG W., ZHANG Y., CHEN M., YANG Q., ZHUANG S., LIANGJU L., ZUO Z., Wang C.J. FEATURE: Environmental Problems and Challenges in China. Environmental Sciences and Technology. 8, 1, 2019.

16. KARTHIKEYAN S., ANANDAN C., SUBRAMANIAN J., SEKARAN G. Characterization of iron impregnated polyacrylamide catalyst and its application to the treatment of municipal wastewater. RSC Adv. 3 (35), 15044, 2013.

17. BUGAJSKI P., CHMIELOWSKI K., KACZOR G. Optimizing the Percentage of Sewage from Septic Tanks for Stable Operation of a Wastewater Treatment Plant. Pol. J. Environ. Stud. 25 (4), 1421, 2016.

18. LADU L.J., LÜ X. Effects of hydraulic retention time, temperature, and effluent recycling on efficiency of anaerobic filter intreating rural domestic wastewater. Water Science and Engineering. 7, 168, 2014.

19. EL-MEKKAWI D.M., GALAL H.R., ABD R., WAHAB M., MOHAMED W.A.A. Photocatalytic activity evaluation of $\mathrm{TiO}_{2}$ nanoparticles based on COD analyses for water treatment applications: a standardization attempt. Int. J. Environ. Sci. Technol. 13, 1077, 2016. 
20. GARRIDO-BASERBA M., VINARDELL S., MOLINOSSENANTE M., ROSSO D., M POCH. The Economics of Wastewater Treatment Decentralization: A Technoeconomic Evaluatio. Environ. Sci. Technol. 52, 8965, 2018.

21. SZELĄG B., GAWDZIK J. Assessment of the Effect of Wastewater Quantity and Quality and Sludge Parameters on Predictive Abilities of Non-Linear Models for Activated Sludge Settleability Predictions. Pol. J. Environ. Stud. 26, 315, 2016.

22. ANDRZEJCZAK O., LIWARSKA-BIZUKOJĆ E. The effect of the pollutant load on the actived sludge flocks morphology. Gas Water and Sanitary Engineering. 12, 480, 2014.

23. EWERE E.E., OMOIGBERALE., BAMAWO., OER., ERHUNMWUNSE., NO. Physio-Chemical Analysis of Industrial Effluents in parts of Edo States Nigeria. J. Appl. Sci. Environ. Manage. 18, 2, 2014.

24. SONUNE N.A., MUNGAL N.A., KAMBLE S.P. Study of physico-chemical characteristics of domestic wastewater in Vishnupuri, Nanded, India. Int.J.Curr.Microbiol.App. Sci. 4,1, 2015.

25. N BENIT., A. STELLA ROSLIN. Physicochemical properties of wastewater collected from different sewage sources. International Journal of Innovative Science, Engineering \& Technology. 2, 11, 2015.

26. TADESU HAILU., ALEMAYEHU ABEBAW. Quantification of Some Physico-Chemical Characteristics of Waste Water Effluent from Batu Tannery Industry at Different Batch, Addis Ababa, Ethiopia. J Environ Anal Toxicol an open access journal. 8, 6, 2018.

27. LIBRALATO G., GHIRARDINI A.V., FRANCESCO AVEZZU. To centralize or decentralise an overview of the most recent trends in wastewater treatment management. J. Environ. Manage. 94, 61, 2012.

28. YAHAYA M.I., AGBENDEH Z.M. Physiochemical characterization and level of potentially toxic metals in surface water around yauria battoir, north western Nigeria. Afr.J.Pure.Appl.Chem. 9, 33, 2015.

29. WOLDEMICHAEL G., TULU T., FLECHSIG G.U. Solar UV-assisted sample preparation of trace determination of uranium by adsorptive stripping voltammetry. Microchim. Acta1. 79, 99, 2012.

30. ESTELLE BAURE' S., EMMANUELLE HE' LIAS. Fast characterization of non domestic load in urban wastewater networks by UV spectrophotometry. J. Environ. Monit. 9, 95, 2007. 